\title{
The Use of Poetic Language in Sarah Kane's Play, Crave
}

\author{
Ansam R. Abdullah Almaaroof, Rudaina Abdulrazak Al-Kumait \\ English Department , College of education for Women- Tikrit
}

\begin{abstract}
Poetic language was very anciently used in writing drama for it was the most suitable language to convey the playwright's ideas. However, its usage had been decreased in the previous time but it is reappeared in the modern age and continues till postmodern age. This paper concerns with the language that is used in Sarah Kane's plays. The paper hypothesizes that Kane has utilized poetic language in writing her play Crave. To endorse this hypothesis, the researcher uses the formalistic approach to analyze the play text. The paper starts with an introduction to the poetic language as well as Sarah Kane's life and work. It presents the method of analyzing the text, then the discussion of the text occurs. The paper ends with the conclusion that winds up the findings that comes in accordance with the being put hypothesis.
\end{abstract}

\section{Introduction}

T.S. Eliot said that "...the forms of drama are so various that few critics are able to hold more than one or two in mind pronouncing judgment of 'dramatic' and 'un-dramatic'" (Eliot, 1950,p. 342). In this sense, to handle the poetic drama is to talk about the critical aspects that critics from Aristotle to Dryden care about regarding poetic drama and thus means to talk about the traditional parameters that the poetic drama once had because poetic drama has a very highly regarded history. Nevertheless, there are very little in common between traditional and modern poetic drama. Playwrights from the Renaissance age differ from the modern and postmodern playwrights in that they have different ideologies and background. It is noteworthy that the period of the seventeenth and eighteenth centuries had witnessed decline in writing poetic drama and it was revived after that but being out of the sight for that long time makes its reappearance at the end of the nineteenth century and early twentieth century very exceptional.

There was no essential, long-lasting form of poetic drama which playwrights agreed upon. Therefore, there were no secure models to follow, expand or act in response to or against. On the other hand, the impact of realism and naturalism in all the fie lds of life spoiled the conventions of the theater which are non realistic but which are of great importance for the style the playwright uses in writing his poetic drama. Thus, dramatists had to reformulate rules which would go well with their aim. Therefore, the modern and postmodern poetic drama is just an exploratory new beginning and not a 'poetic drama movement' as such. In fact, it is only that there are but a number of dramatists from diverse times and places who write plays by using poetry. They try to react against the traditionalist of realism in the commercial theatre. They are willing to conduct experiments to connect form and content to the twentieth century, far from imitating Shakespeare's style. The writers are different, however, there were relations and influence. 
Gradually, the dramatists were conscious that modern and postmodern poetic drama was a distinctive genre. W. B. Yeats (1865-1939) is the pioneer of this disseminate movement. He rebuilt the structure, the content and the poetry form. (Leeming, 1989, pp1-2). In this regard, poetic drama though has no fixed rules but it is very important factor for any drama to be poetic is to use poetic language, hence, this paper concerns with the use of poetic language in the postmodern playwright, Sarah Kane's play, Crave.

\section{Methodology}

Poetic language concerns with the form as well as the content of the text. Formalistic approach, consequently, is the most proper tool that the paper uses to analyze the selected text, Crave, since it focuses on the form as well as the content. It will help the researcher shed light on the use of the poetic language and the function that it has accomplished throughout the play and its importance in conveying the message that the playwright tries to clarify.

\section{Sarah Kane's Writing}

Sarah Kane who was born in 1971 and died in 1999 is a British playwright. Her plays deal with many themes, pain in love, physical and psychological agony, redemptive love, death, and sexual longing, drug addiction, are among many others. Her plays are famous for their examination of theatrical structure that derives its power from the violent graphical images which are usually used by the playwright. The use of severe and violent stage acts is also distinguished in her plays. Kane and her critics, among them, Graham Saunders, identify some of her motivations like Jacobean tragedy, and expressionist theatre. What is more, In-Yer-Face theatre is another form of theater to which Kane's plays belong. This suggestion is made by the English critic, Aleks Sierz. It is a term first coined by him. It stands for a form of drama that leaves the conventions of the naturalistic theatre and it cause a shock for the audience as if they are given a hit. (Sierz, 2001, pp. 120-121)

All that Kane has left is five published plays starting with Blasted, and ended with 4.48 Psychosis, as well as one short film that is called Skin which is published too. Moreover, she had two newspaper-articles which are written for the sake of The Guardian for she had led a very short life. (Saunders, 2002. p. 224.) Kane has found in theater a wide scope for better expression of the self, about which she once said," theatre has no memory, which makes it the most existential of the arts...I keep coming back in the hope that someone in a darkened room somewhere will show me an image that burns itself into my mind".( $\underline{\text { https://art- }}$ sheep.com/touching-love-monologue-from-crave-by-sarah-kane/)

\section{Poetic Language}

No matter what the subject of drama is, the most important thing is that its form has to be like that of a sonnet in its perfection and underlying unity. Dramatists themselves are in disagreement regarding the main purpose of dram; Ibsen throughout his plays, conf irms that drama can be of a social core, Shaw, in his turn, practically ensures that drama is essentially of a radical set of guidelines, while Maeterlinck literally suggests that it may be the most insubstantial and delicate of the insight, or as Sarah Kane presents in her plays that drama can be about violence and cruelty that become widely used in the whole world.

Needless to say that language has an important role on the stage just like the role that it has in real life. It is the first and foremost way of communication among many other ways. Critics 
consider it as the most outstanding feature in creating drama. It is used to portray characters on the stage as well as actions. It has this distinguished significance for it is the only means to replace other means. It can in combination with facial expressions only present a full drama. (Bentley, 1979. 8)

Although dramatic language is artistically prearranged like the language in other literary genres, it has many features that distinguish it from that of other genres. These features can be as follows:

1- " language in drama is represented as spoken language,

2- dramatic language deviates from everyday language,

3- and finally language in drama is represented as direct speech." (Elke 1999, 128)

In this sense, these features led to a practical fact that is the dramatic language has many functions that serve the structure of drama and its performance. These functions as Bernhard states are as follows:

1- "the referential function,

2- the expressive function,

3- the appellative function,

4- the phatic function,

5- the meta-lingual function,

6- and the poetic function." (Bernhard 1990, 8)

What this paper concerns with is the poetic language of Sarah Kane's plays, which are written with a British pen. The paper hypothesizes that Kane has presented her play; Crave(1998), as poetic play, unlike her earlier plays which show violence and cruelty. The paper shows how the use of such language contributes in clarifying the theme of the play to the audience.

\section{Discussion}

Though Crave is a one-act play, but it is expressive in its linear style. The use of language in Crave is very notable. The play has a great quantity of chatting, and a variation in its conversation style. On the other hand, it has a small number of scenic directions and they are unspecific. The characterization of the play, in its turn, is very distinguished in that they are not having frank names. All that they have are mere letters; A, B, C, and M. They are virtual anonymous. Thus, nobody can identify to whom the speech is directed in a certain moment. The director is the one who can portray the whole scene since he is the only person who can determine the addressee of certain statement. In this regard, dealing with such characterization as those in Crave, and presenting them on the stage in a clear way so that they can be recognized by the audience as four different persons who have disjunctive features need very outstanding direction skills. Nevertheless, the language used by these characters which cunningly designed by the playwright helps facilitating the presentation of this diversity. In the following conversation:

"C: And has been hurtling away from that moment ever since.

A: I shudder with grief for that moment which I've been hurtling away from ever since."(Kane, 2001, 162)

Kane has exposed two parallel relations; the relation between $\mathrm{A}$ and $\mathrm{C}$ on one hand, which is described as hurtling. "Hurtling" is an unusual word which means that C's grand- mother, A, unlike her grand-daughter, $\mathrm{C}$, is an experienced woman. On the other hand, the relation between $\mathrm{b}$ and $\mathrm{M}$ is depicted as hurtling too. It is a relation between a middle-aged woman $\mathrm{M}$. and a 
young man, B. while B. is attracted by M., M. needs a child from B.. Thus, their relation is problematic. In this sense, the playwright has succeeded in creating a poetic image of craving love by these characters from the very beginning of the play, from the title, Crave. Searching for love becomes an affection for each of them. It is very obvious when C. declares:

"C: I Crave white on white and black, but my thoughts race in glorious techni-colour, prodding me awake, whipping away the warm blanket of visibility every time it swears to smother my mind in nothing"

(Kane, 2001, 174)

$\mathrm{Or}$

"Don't fill my stomach if you can't fill my heart"

(Kane, 2001, 187)

The theme is obvious in the play from the beginning. Beside using the language to build an image of craving by choosing the word Crave to be the name of the play, Kane has employed other verbal techniques, among them, the use of rhyme when $\mathrm{C}$ says: "Assimilated but not obliterated." The rhyme here is in the same single line. In the same way, it can be heard in a couplet as well, as in:

B: She wants a kid yesterday.

"A: what will I do if you throwme away? (Kane, 2001, 105)

Or it may take another form such as postponing the answer or leaving the answer to be understood throughout the line of the play, as in:

"B: Are you a lesbian?

M: Oh please.

B: I thought that might be why you don't have children."

(Kane, 2001, 161)

The reader as well as the audience can easily notice that the playwright does not depend on using meter in writing her play. Rather she relies heavily on the use of stanzas:

"C: Looks like a German,

A: Talks like Spaniard,

C: Smoke like a Serb."

(Kane, 2001, 156)

This stanza is a preparation for the audience. It is followed by macaroni- lines. They occur at almost equal intervals. According to Ruby Cohen's statement, there are seven utterances in foreign languages. They contain three Spanish utterances, two more German, and the other two are Serbian utterances. (http://revel.unice.fr/cycnos/index.html?id=1668) It is notable that all of them are said by B. The audience can also observe that rhyming words are also used in the play:

"C: Leave.

$B:$ Where?

C: Now.

M: There."

(Kane, 2001, 157)

In spite the fact that these words are rhymed, they are different. Actually, they have various pitches due to the fact that they have different functions. For example, "where" is a question while "there" is an answer.

Poetic language is also evident in the play in the use of repetition that creates a very strong stress. The play starts with C saying: "you are dead to me".(Kane, 2001, 155) This statement is repeated four times in the play. However, the listener is unknown by the audience. It almost that the whole 
society is dead for the speaker. The ambiguity of the identity of the listener as well as the repetition create a great amount of anxiety and worry in the atmosphere of the play as being delivered to the audience.

On the other hand, repetition occurred in the text to declare the protest of $\mathrm{M}$ and $\mathrm{B}$ which is also apparent throughout the play:" It is just not me." Or/ and B's and C's reiterations: "I feel nothing, nothing, Ifeel nothing.".(Kane, 2001, Pp. 156, 158 and 199) They are different when say: "I did nothing, nothing, I did nothing". (Ibid. 179) However, the being used verbs are belied later in the play. Noteworthy that the playwright despite the lack of recognizing the characterization of the play, she never gather the four characters in a speech, throughout the whole play.

Reading the play shows that there is an extended speech which takes about two minutes in performance on the stage. It is a continuous speech that covers about two printed pages in the written text. It reminds the readers and the audience with the long monologue of Lucky in Beckett's Waiting for Godot.

By contrasting, in this speech, Kane's professionalism in using the language is palpable. She use s short sentences along the line of the whole play to give the audience a kind of shock when such a long speech occurs. The audiences are obliged to listen to A for about two minutes to deliver the monologue about the craving love: "[...] somehow somehow communicate some of the loverwhelming undying overpowering unconditional all-compassing heart-enriching mindexpanding on-going never-ending love I have for you". (Kane, 2001, 169-170) But what differentiates these words from Lucky's is that these words are shared from the slash mark $(/)$ on between A and C. whereas lucky's speech is a monologue.

Another aspect that proves Kane's usage of poetic language in Crave is that she does not use violence and cruelty in structuring the play as she uses to do in building the structure of her previous plays. Instead, she utilizes various verbal devices such as quotations. The audiences are to find that $\mathrm{B}$ and $\mathrm{M}$ are speaking four lines which are borrowed from The Waste Land of $\mathrm{T}$. S. Eliot. The playwright takes these four line to achieve two points; one is the full depiction of the image of drought which serves and comes in accordance with the theme of the play, and the second is the use of quotation technique to employ inter-textuality.

Religious reading of the playwright is apparent in the play. "The Bible of Job" is another source of quotation which is used by Kane in writing Crave. It is a quotation of about five line said by $\mathrm{C}$ near the end of the play:

"Let the day perish in which I was born/ Let the blackness of the night terrify it/ Let the stars of its dawn be dark/May it not see the eyelids of morning/ Because it did not shut the door of my mother's womb"(Kane, 1998, P.37)

Quotations from the Bible continue to be intermingled throughout the text from this point on. A says:"But God has blessed me with the mark of Cane". And also says:"Glory be on the Father" and "Which passeth all understanding". Moreover, there is A's;"World without end " which comes before M's "Glorious. Glorious" and followed by B's "And ever shall be"(Kane, 2001, 190). All these quotations serve and add to the poetic nature of the text.

The speeches are varied between original and quoted throughout the play, nevertheless, it is with C's words that the plays closes. "Happy and free" which is the last declaration of C. as feeling happy and free which is the ultimate goal that is achieved by $\mathrm{C}$ at the end of the play. Kane belief that it is only with death that one may obtain freedom and happiness is conveyed via this 
statement. Early in the play, C has had a wish when she said;"If I could be only free of you without having to lose you."(162) It seems that her wish becomes true at the end of the play. Finally she becomes happy and free. The audience as well as the reader can find throughout the play that there is a reason behind her being happy and free. If the readers or/and the audience follow the speeches of the play, they can straightforwardly bring to a close sight that all the characters put great emphasis on the words which are spoken to each other as well as the use of language. For example, A says with aggravation, "I don't have music, Christ I wish I had music but all I have is words".(184) C, in her turn, says with more aggravation; "I hate these words that keep me alive. I hate these words won't let me die." B also speaks out:

"And don't forget that poetry is language for its own sake. Don't forget when different words are sanctioned, other attitudes required. [Sic.] Don't forget decorum. Don't forget decorum " (Kane, 2001, P. 199)

About the end of the play, it is noticed that the characters have forgotten the decorum or at least neglected it. They returned to the rhythm of the Bible with which, freedom and happiness are finally obtained. In this sense, the play is sophisticated in its structure, in that neither the reader nor the audience can follow its action. All that they can follow is words.

It seems that the playwright intends to create an objective correlative to the happiness and freedom that the characters seek. The language is the best element in the text that can be that objective. It is the means by which the idea is conveyed. The whole characterization follows the poetic language- with all its regulations- throughout the play. This stands for the severe restrictions that people have in their daily life. It is only at the end of the play that the characters gain their happiness when they break all the rules and get freedom and that is achieved in the text by breaking the objective correlative which is the poetic language.

Kane has her own vision in creating a text just like a long poem in the form of a play. The play has a unity in the idea and this is quite clear when it starts with C. says, "you're dead to me" (155) and to be closed with the same statement which is spoken by the same character, C. herself (200). This means that the whole play is an accumulation of the fragments that appear along the line of the text.

\section{Conclusion}

To sum up the findings of the paper, it is through the use of poetic language that Kane succeeds in conveying the idea of anguish and agony that the character live in because of their craving towards unobtainable love. Using poetic language is evident throughout the written form as well as the performance. Crave is a breakthrough in Kane's writing style because with which she has departed violent and cruelty theater to another form of drama. Via composing poetic drama, Kane has achieved her everlasting desire of being a poet which has never achieved throughout her previous writing because with poems she could not express her feelings and thoughts vividly. It is obvious that poetic drama has given Kane what she's keen to obtain.

\section{References}

1- Bentley, Eric.(1979) The Life of the Drama. New York: Atheneum.

2- Elke Platz-Waury, (1999). Drama und Theater: Eine Einführung (Tübingen: Gunter Narr.

3- Bernhard Asmuth, (1990). Introduction in The Drama Analysis. (Stuttgart: Metzler 1990. 
4- Cohn. Ruby, "Sarah Kane, an Architect of Drama". In Cycnos $\mid$ Volume 18 n1 Le théâtre britannique au tournant du millénaire - in http://revel.unice.fr/cycnos/index.html? id=1668. Retrieved in $11 / 3 / 2018$.

5- Eliot, T. S., (1950) 'The Poetry of W. B. Yeats' in Hull, J. and Steinmann, M. (eds), The Permanence of Yeats .New York: Macmillan. Google Scholar.

6- Kane. Sarah, (2001). "Complete Plays: Blasted, Phedra's Love, Cleansed, 4.48 Psychosis, Crave, and Skin". London: Methuen.

7- Leeming G. (1989) Introduction: Poetic Drama and the Twentieth Century. In: Poetic Drama. Macmillan Modern Dramatists. Palgrave, London.

8- Saunders, Graham (2002). Love me or kill me: Sarah Kane and the theatre of extremes. Manchester; Manchester University Press:2002. p. 224

9- Sierz, Aleks (2001).In-yer-face theatre: British drama today. London: Faber and Faber. pp. $120-121$.

10- Touching love monologue from 'Crave' by Sarah Kane". In (https://art-sheep.com/touchinglove-monologue-from-crave-by-sarah-kane/). Retrieved in (12/4/2018) 